\title{
Footballers and Conductors: Between Reclusiveness and Conviviality
}

\author{
Anders Høg Hansen
}

\section{INTRODUCTION: HISTORIC OCCASIONS-A FOOTBALL Match AND A Human Exhibition}

In a personal correspondence in April 2018, British cultural theorist Paul Gilroy comments on a particular event concerning one of the cases of this chapter.

It was clear that this was a historic occasion and I was delighted to have had the chance to witness it / Laurie had lit up that season and we all knew he was leaving so there was a mood of farewell about that. He and I are the same age and grew up in the same area of London so I always had a particular identification with him / The game wasn't much though it was nice to see so many black spectators in the ground. Laurie took one of those artistic corner kicks.

The historic occasion which Gilroy commented upon was 'just' a testimonial football match for a player named Len Cantello that took place

\footnotetext{
A. H. Hansen $(\bowtie)$

Faculty of Culture and Society, Malmö University, Malmö, Sweden e-mail: anders.hog-hansen@mau.se

(C) The Author(s) 2020

O. Hemer et al. (eds.), Conviviality at the Crossroads, https://doi.org/10.1007/978-3-030-28979-9_12
} 
40 years ago, on May 1979 at the UK football club West Bromwich, just outside Birmingham. However, it had a particular formation of players that made it novel, at a particular time in British history-and in football history. Gilroy mentions a Laurie. That was Laurie Cunningham (from now on just Laurie), characterised as a soul boy, music-lover and dancer by his biographer Dermot Kavanagh (2017: 44)—often gliding elegantly over the muddy pitches until envious tackles began to damage his promising career. Laurie was on that day in May 1979 in a team of black players-of African-Caribbean heritage-only, gathering most of the few black players that played in the British football league at the time. They were up against a more common sight: a team of white players only, including Len Cantello. All the black players dressed in white, and the opponents black and white stripes and black shorts. Testimonials were commonly ritualised and celebratory affairs - and this one was too, yet with an added edge or surprise in its way of addressing colour, multiculture and competition in contemporary football in Britain. BBC TV journalist Adrian Chiles in 2016 made an hour-long TV documentary Whites vs. Blacks: How Football Changed a Nation that included new interviews with many of the former players, now in their late 50s. In 2017, the first and only biography on Laurie Cunningham came out (by Dermot Kavanagh). One iconic image depicts Laurie with his West Bromwich teammates, the muscular forward Cyrille Regis, captain of the black team at the match and defender Brendon Batson. The three players were that year to be nicknamed The Three Degrees (after an American female soul trio) - and in a recent book called 'The Men who changed British football forever' (Rees 2014). ${ }^{1}$

West Bromwich is next to Handsworth in Birmingham, documented some years later (1986) in filmmaker John Akomfrah's ${ }^{2}$ debut documentary Handsworth Songs. Close by too was the home of Centre for Contemporary Cultural Studies, at Birmingham University. At the time of The Three Degrees and the testimonial, the Jamaican-British media and cultural studies scholar Stuart Hall was leading the centre in his last year in office. ${ }^{3}$ A postgrad research student of the centre at the time, around 1979, was Paul Gilroy. In his footnotes in one of its working paper collections (1980), he notes his joy of watching West Bromwich on Saturdays. In the late 1970s and early 1980s, I followed them intensely, the English league being televised every week - and I was most often in the armchair in the front of the then black and white TV (Fig. 12.1). ${ }^{4}$

The black $\mathrm{v}$ white testimonial event-alongside other popular signs of integration as well as disintegration and tension in late-1970s Britain-can 


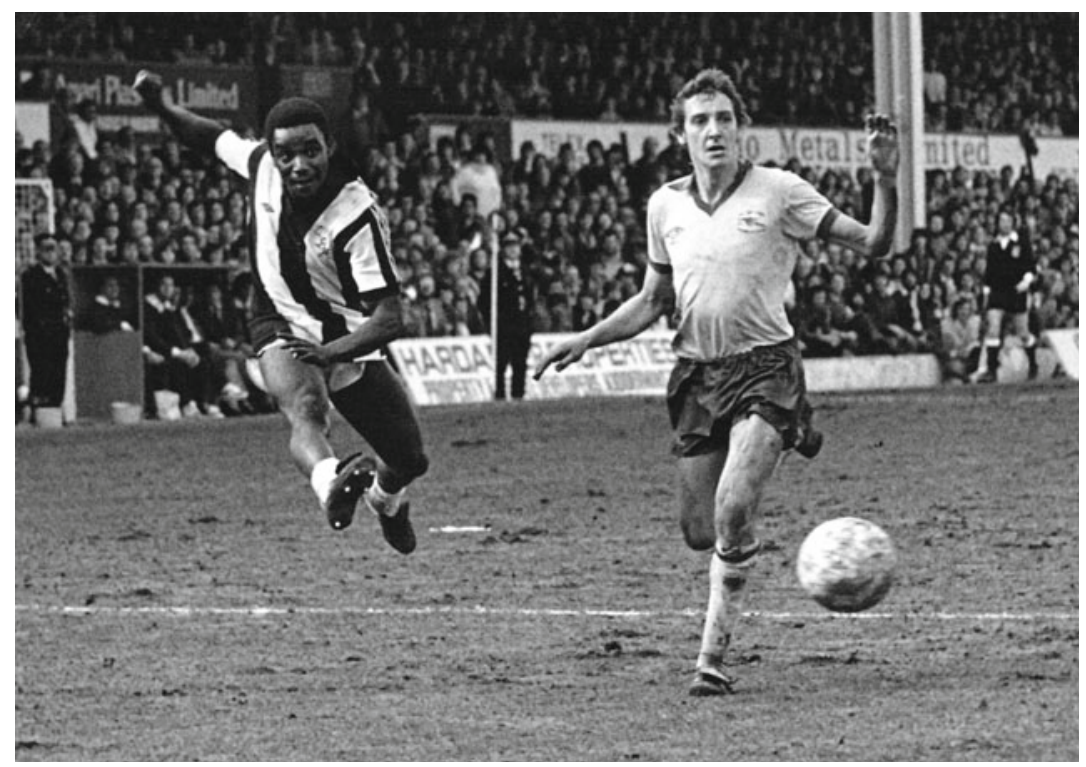

Fig. 12.1 Laurie Cunningham in action for West Bromwich, 1979 Alan Williams/Alamy Stock Photo. This image is not included in the Creative Commons Attribution 4.0 International License

be seen as a significant echo of a heritage of colonialism. The tension which characterised the cities in the midst of economic crisis was turned into a more cheerful spectacle.

The TV documentary, the Cunningham biography and recent writings and events (a memorial sculpture on The Three Degrees was launched in West Bromwich in May 2019) mark a renewed focus on particular black players and tensions in British football. Laurie is my first case of two. The second case $\mathrm{s}^{5}$ is also concerned with Caribbean migration and a form of living memorial of colonialism. It is about the St. Croix-born Victor Cornelius (from now on just Victor), who in 1905 was shipped to Denmark as a 7-year old, alongside his 4-year-old half-sister, Alberta Roberts. They were going to be extras in a human exhibition at a colonial festival at the amusement park Tivoli, Copenhagen (Freiesleben 1998; Frank Larsen 2008). The Danes, it seems, needed black subjects from their colonies to amuse them with. Victor and Alberta were picked from poor widowed mothers at the then Danish-owned colony of St. Croix in the Caribbean Virgin 
Islands and sailed to Denmark. Victor ended up staying in Denmark all his life, while his half-sister Alberta died in Copenhagen of tuberculosis aged only 15, in 1917, just weeks before the Danish Virgin Islands were sold to the USA (that had developed a strategic interest in the islands during World War I).

A few years later Victor was a successful student at a teacher's college outside Copenhagen. Image 2 turns the human exhibit positioning of Victor around completely. Here we see a free-spirited Victor, confidently posing and 'conducting' his life, literally, with fellow musicians at the teacher's college.

During 2017-2018, the 100th anniversary year of the sale of the islands, this historical legacy of Denmark's colonial past is re-opened through art pieces, historical debates, and exhibitions and monuments. The Danish colonial history had by no means had a proliferate public coverage or clearly visible place in the school curricula, yet 2017 marks some kind of turning point. In the midst of a variety of initiatives and public debate, an exhibition about Victor appeared in small-town Nakskov-assisting the sculpture of him at the train station square, in the town where he worked all his life after graduating teacher's college at Jonstrup college near Copenhagen. Victor had written his own autobiography back in 1977 and since then he has been documented by several writers and a filmmaker, notably Birgit Freiesleben in 1998 and the journalist Alex Frank Larsen, in 2005, in a TV documentary and book about Danish descendants of the country's former colonies (Fig. 12.2).

\section{Living Beyond and Within Race-RecLusive Openness, Opacity, Conviviality}

The quite different journeys of Laurie and Victor developing their talent in two Western postcolonial societies mark particular strategies of playing and living with different allegiances which I will begin to develop. Nowicka and Heil, in their work on cosmopolitanism and conviviality (2015), argue that there are plenty of peaceful situations in which people live or/and work 'beyond their identities', and 'despite their differential positions in social structures' (2015: 12). The mainly British footballers of the testimonial match (the black team of Caribbean or African heritage), in most cases from a working-class background, mirrored a particular positive dynamic or integration. A thrown-togetherness for fun and play, but also a clear 


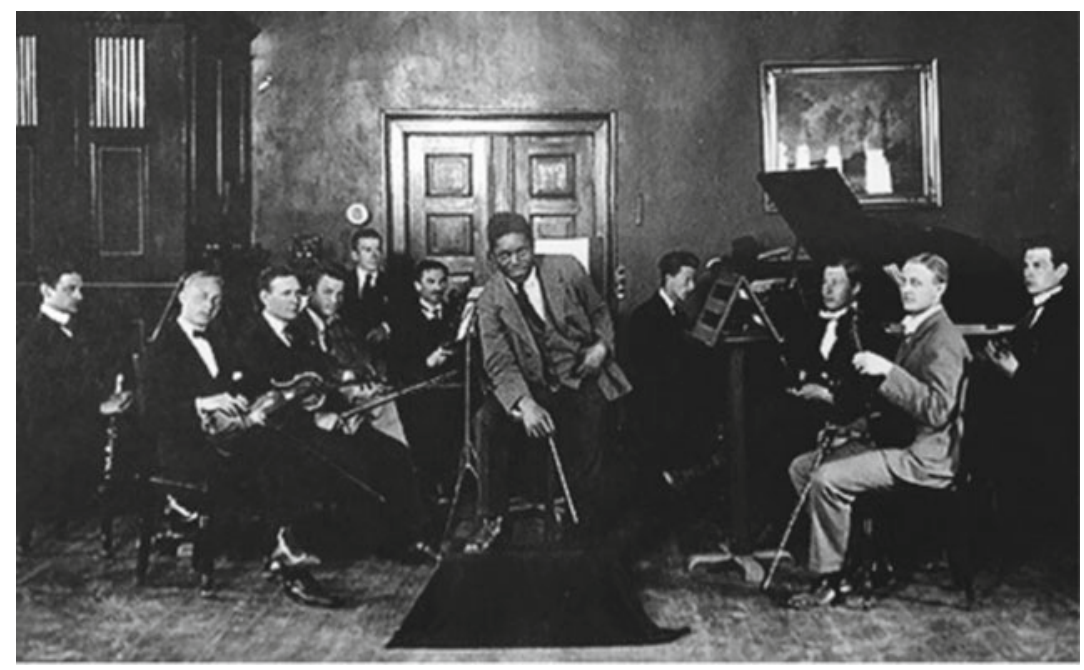

Fig. 12.2 Victor conducting. CC BY-SA License/https://commons.wikimedia. org/wiki/File:Cornelins_1.jpg

expression of antagonism and destructive tensions characterised the country. A wave of so-called muggings had filled the media most of the decade (see, e.g., Hall et al., Policing the Crisis, 1978), since Powell's infamous speech 10 years earlier, ${ }^{6}$ tensions had risen and a new crisis had captured the former empire, with Thatcher taking over. On the football pitches, in dance halls/clubs and as well in band formations, as in the second wave of ska/blue beat, some other signs of peaceful play were prominent, but so was the general fragility.

In addition to articulation of postcolonial forms of predicament and expression in both cases, the UK case draws from allegiances and connections between football, music and a crisis of industry, while the Danish case also marks a turn-around or redemptive figure, which also could be used as a perfect early example of integration? Victor turned his life around from a colonial exhibit to a carrier of Nordic/European choir music values and teaching. From his youth and onwards, Victor began to establish musical meetings and festivity that encouraged new forms of interactions and carriers of the convivial, or something sacred for those with interest and skills (not necessarily in a religious sense although he also turned strongly to religion, as documented in his biography, 1977). Importantly, his teaching 
and notably his work on music and his choir became vessels for those he sang or worked with to express themselves.

Both Laurie and Victor, I argue, need a specific theorisation to make sense of their ambiguous roles, as wilful tricksters, I would put it, yet also enigmatic and self-protective. Drawing upon the notions of reclusive openness and conviviality, in particular, I will open the discussion. The notion of reclusive openness (self-coined) could be an oxymoron. It may convey the tense ambiguities of diasporic and displaced identities (Cohen 2017). The word reclusive may be traced to the French reclus, an adjective describing a person who hides. Often with the purpose of meditation. A person or a group may become reclusive - in particular when faced by a majority culture. One may as a way of coping try to find track(s) for survival-and maybe in that process develop or create one's own openness. Openness is in philosophy a state of transparency and also in our era a cherished state of free and open access to information and data. However, we may try to rethink reclus and open together as a form of conviviality where more protected communicative spheres and 'caves' lead to another kind of openness, identity development and cohabitation. This leads me to the next point, trying to elaborate on a third notion carrying a stronger note on the postcolonial predicament. I am referring to a situation as well as process of living reclusive openness; An opaque and changing state, where identity is never clear or singular. Glissant's notion of opacity may be able to capture this ambiguity and lack of transparency-and furthermore help to nuance the notion of the reclusive, but also to add a creolity or complexity of openness of identity. Difference is here in a space that is neither elitist, ethnic, nor subcultural, but diverse within, as a habitual ideal.

Reclusivity or what we could also call a form of with-drawnnesswhether pushed back or willingly seeking such a protected state-can lead to another state of being. Such as, an openness within a community or in spaces where one feels that he/she can perform and be what she wantslike e.g. Laurie's dancefloor, football pitch or Victor's music classrooms or white choir practices which may be seen as such spaces 'beyond identity' in Nowicka and Heil's sense.

Let me explore some general understandings of the reclusive and its implications for thinking around gaze and race. As Meghan Tinsley noted (in a response to an earlier version of the chapter), the involuntary reclusiveness of the racialised subject may be liberating? (Tinsley 2018). A black person is in Western contexts largely subjected to a white gaze and surrounded by a white majority that does not live sensing its own colour/race. Tinsley 
connects her point to Glissant's notion of opacity. Glissant's opacity or a right to opacity (Glissant 1997) operates with a 'stubborn shadow' (Simek 2015), a fuzziness or a creative repertoire of surprise which performs in parts as attempts to escape a framing gaze. A performance or modes of deflection that does not quite make the white/powerful able to understand or read you. The opacity is here in parts a tricky veiling or a disguise of tricks (apropos creolity), which the subject uses tactically to escape the gaze and reinvent herself or make him not readable/transparent. This creates a situation where the white cannot read the black, while this 'you', the black, were fully able to read the white/the coloniser-the latter reasoning inspired by Bhabha's discussion of mimicry (1994: 85-92). ${ }^{7}$

Both Laurie and Victor had such repertoires. Laurie was an enigma in the dressing room, kept to himself. Yet, he was also quite expressive and flamboyant - in clothing and on the football pitch — and also on the dance floor, where he spent just as much time as on football (Kavanagh 2017:49). Kavanagh writes that a person that dressed so lavishly might be assumed to be extrovert, but on the contrary he was not. Cautious with strangers, he was-and; 'the clothes he loved to wear sent out a message so powerful that they succeeded in deflecting attention away from the person wearing them' (2017: 75) — a sign of a tactical or habitual opacity? The singular Laurie easily splitting himself up in several stage personas or 'multiplicities' (Rodwick in Demos, debating Glissant 2009: 123)? Opacities can coexist and converge, as Glissant writes (1997: 191).

The artistic kicks Gilroy mentioned (quote at beginning) was performed by doing corner kicks with the outside of his foot, with the left foot from left side of the pitch, and right foot at the other side. Laurie was not alone in his desire not to conform, but he had something else, his silky skills and dressing, his floating on the pitch. His athleticism produced an offer of a tour with a Harlem ballet ensemble. Furthermore, as many of his fellow black footballers, he chose not to respond to banana throwing and stick during games. Several black players of the time said that they heard every utterance of racism but tried to channel it into an urgent focus on the game instead (e.g. Regis 2010; Hazell in Chiles 2016; Kavanagh on Laurie 2017). This can be seen as one way of trying to stay opaque or nonconfrontational, not by submitting to the humiliation, but by 'avoiding the tackle' and frustrating the racist roarers. 


\section{The White Choir-Victor in Nakskov}

My introduction to Victor Cornelius was assisted by an image of the man in convivial control. Pausing for a pose during a musical situation, with Victor at the centre, conducting. I now return to him with another group of music folks: singers from his choir of nurses formed around 60 years later set up to sing for patients in hospitals. The choir came about when Victor is in bed in the hospital of Nakskov in Southern Denmark some years earlier. Treatment is going well and when he is fresh enough to sit up, his doctor, Jokum his name was, tells him to play a song on his Hohner harmonica. He chooses a Swedish waltz. Soon nurses and other patients join in dancing. When he is fresh enough to stand he plays regularly for his hospital ward. He survives the cancer and sets up the White Choir in Nakskov singing at local events, in churches and in the hospital. Similar choirs are established in the region (Fig. 12.3).

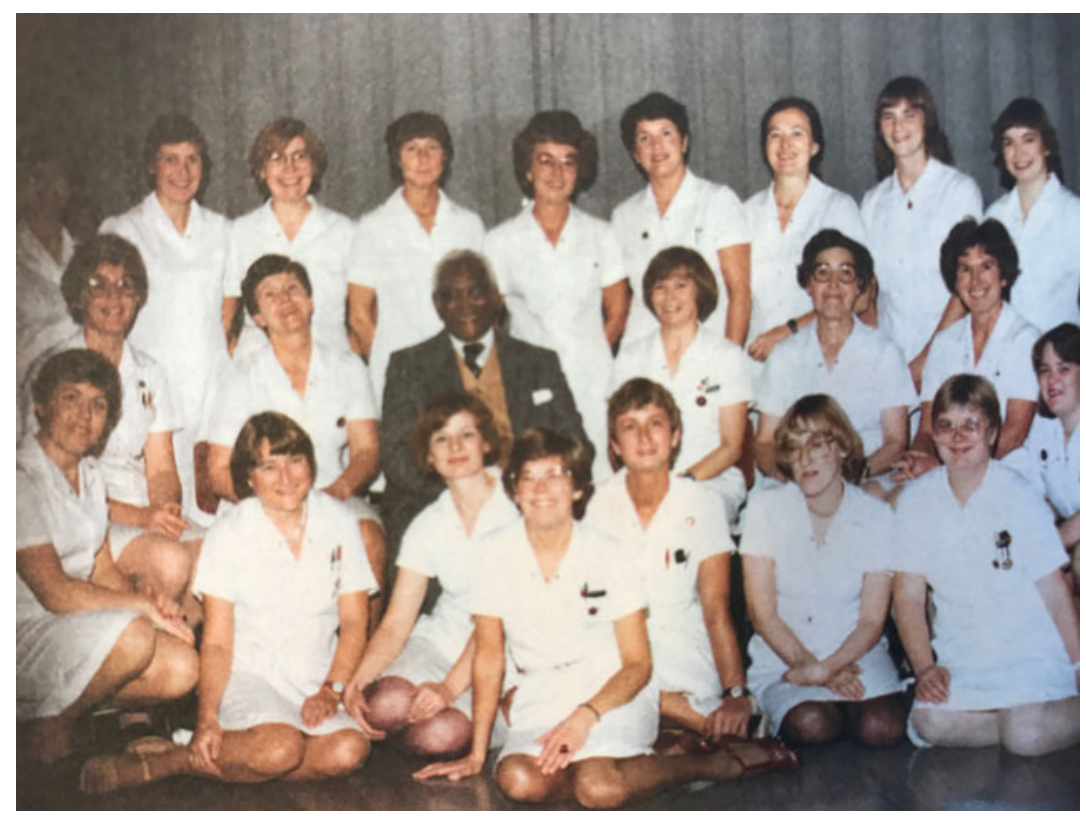

Fig. 12.3 The White Choir 1981. CC BY-SA License/https://commons. wikimedia.org/wiki/File:Cornelins_3.jpg 
In his autobiography (1977), Victor recalls a particular moment after arrival in Denmark when he became an extra in the colonial festival in Tivoli. Victor is eventually caved to stay put-since he constantly ran over to the Greenland-sections, not wanting to stick around in the arranged Caribbean space. When put into a cave, he spits on a notable getting too close (Cornelins 1977; Frank Larsen 2008). The two met many years later and reconcile on warm terms, a mark of Victor's conviviality. So humiliatingly abused to begin with, but able to turn it around and to meet anew and embrace the person that came to look at him as an animal.

After the spitting event in Tivoli, 13 years later, St. Croix and 2 other Danish-owned Virgin Islands, where Denmark earned a massive income on slavery at sugar plantations for over 150 years, were sold to the USA. Victor was allowed to stay in Denmark although authorities had tried to persuade him to continue schooling in the USA. He did not want to leave. He was doing well at Jonstrup teacher college in Denmark where he often takes up the role as conductor, as noted earlier in the chapter. He became a school teacher and then deputy inspector at a Nakskov school, where he also taught music.

In 2017, I met one of his former music students, Timme Ørvad, who says that he does not know how Victor got around to do teaching and administration too, it was music, which was his passion. He says the following about a school friend (later to be his wife) and his own introduction to music: 'My wife played violin with him and she sang in a girl choir he set up at the school, while for me the guitar fell down in my hands', Timme explained (Ørvad 2017). Timme and his future wife were both influenced by Victor. They proceeded to the music conservatory in Copenhagen and became music teachers and composers.

\section{BLACK AND WHITE}

Today, a third of the top English football league's players are of AfricanCaribbean origin-much in disproportion of the few per cent of the population they number (in addition to the many non-UK players brought to the premier league). The multi-ethnic outlook of the English premier league is if not unremarkable, then at least a reality where its important turning point was back around 1979 when there was only a handful of black players in the top league, including those three mentioned at West Bromwich in Birmingham. At the testimonial are also three other top-level black players, Hazell and Berry from Wolves (also a midlands club, a rival) and Crooks 
from Stoke. Crooks, today a football commenter, was missing from Adrian Chiles 'Black and White' TV documentary from 2016, mentioned in the introduction.

In the documentary, Chiles not only tracks down many of the players of the time and interviews them about the event. He also follows up interviewing more recent generations of players, to get a sense of changes in the game. Nobody wants to take the credit or the blame for the original idea for this white and black game, Chiles says-although a recent The Guardian article by Simon Burnton (2016) claims the idea coming from Cantello and Regis discussing the event. They thought this set-up would cause attention-and produce some additional quid's in retirement bonus for Cantello via more people on the terraces. The game was well visited for a testimonial. The Guardian, back in 1979, called it 'tasteless' and noted it could ignite violence among the crowds. It went by peacefully. Chiles peculiarly keeps the whites and black separate also in the interviews, apart from a final convivial get-together of players from both teams. A bunch of well-known white players says they hardly remember the event-but had noted that there were more Asian and black people on the terraces than ever before. These groups were following football on TV-but many were scared to enter the stadiums where they risked rubbing shoulders with the National Front.

The black players, on the contrary, remembered it as something special. They noted that they were making history and this was a fantastic event for them. 'A novelty thing, which was fun', Brendon Batson said, who since has worked in the Football Association advocating for more black players to become involved in managing roles. The testimonial was a sign that a problem was recognised and performed and not ignored anymore. They now spoke of the emerging collective using a broad category of ethnicity or African-Caribbean heritage. All the black players had heard about each other, but they were spread out as a minority that on their own had to conform to the white game and the shouting. With the testimonial they were granted an opportunity to come together and built and extend their community, uniting with other black players who had been through the same trials. In the dressing rooms, racialisation was played out on another level of embodied conviviality. One thing is the tackles. Then there is the banter, the stripping naked, and the sharing of creams. 'what's going on there?' 'Daren't put it on', older white players would respond (Back et al. 2000: 152). 
Outside on the stadium terraces, large parts of the mainly white spectators in those days regularly threw racist jargon and bananas at black footballers. They may have become approved in the rites of the fans, as long as they were one of our boys (Mercer in Back et al. 2000: 76), but as Cyrille Regis, one of the black West Bromwich players, said it. 'At the time we were going to Millwall, Chelsea and Tottenham and 10.000 were singing nigger, nigger, lick my boots'. Regis dies suddenly of a heart attack, aged 59 , in early 2018 (while the previously mentioned memorial statue for The Three Degrees, depicting Laurie and teammates Regis and Batson, was in the planning phase ${ }^{8}$ ). Regis cortege passed by the stadium in West Bromwich and a special service was held there. Back in 2008, he was made MBE, member of the order of the British Empire, for services to the voluntary sector and to football (Regis 2010: 237-238) 2010. Queen Elisabeth pinning the medal on his chest is also included in the picture section of his autobiography (2010).

The players of African-Caribbean heritage who lived with the problem and just had to continue playing had for that fleeting event thrown themselves together as a force. One of the young talented teenage players, Vernon Hodgson, had to put his career on hold after the 1979-game due to a bad knee he had had for a year. He went to drink heavily for some years, but was saved by the bins, as he says to Chiles, when Chiles found him at work as bin man.

Black youngsters, many second-generation Caribbean or arrived in the UK as children, were at the time around 1979 in different ways exploring belonging to Britain-and through sports and music carving out new routes of identity. Laurie often invited fellow white players with him to black music clubs in Birmingham. It was a time where Ska revival and post-punk merged audiences and playing spaces and bands among black and white people. However, also particular racist fractions of skinheads created tense friction. Conviviality and conflict lie close (Nowicka and Vertovec 2014: 346, using Karner and Parker research from a contemporary study of Birmingham, UK). Dancing to the new music and shouting white supremacy. Suggs from one of the white bands, Madness, that built themselves on Jamaican Prince Buster with their initial ska-sound, once explained that they were performing to fractions of the more radical skinheads doing racist chants and sieg heil. The music, on the other hand, an embrace of the new Black Britain, was as far from that salute as it could be. The Skinheads had initially removed themselves from the middle-class hippies and 
embraced the Jamaican dance moves and music which they thought were cool. Yet, the racism lived. It was ambivalent times.

The Birmingham area, including Coventry, where some black and white Ska-bands emerged from, was a stronghold for promoting integration, maybe even colour-blindness. However, the National Front fans and the racist fractions of skinheads were also on the terraces shouting and throwing bananas at black players. The gloom and doom of the post-industrial city and the era, though sparkled with new popular music fusions, are captured in The Specials (black) swan song and video Ghost Town (before a split and a reformation as AKA Special).

Almost 40 years later, Chiles' documentary can be interpreted as a rather pleasing pad to social progress since the roars on the terraces, muddy pitches and ghost towns, yet with a definite sting in the tail, as Jasper Rees notes (2016). Racism has now moved from the terraces into social media, according to several contemporary and recent players. Director Chiles also met Les Ferdinand, a former black footballer, presently Director at QPR, and one of the few former footballers of African-Caribbean heritage to reach a management position." 'We can make as many of these documentaries as you like', he warned, 'but you won't change what's in people's heads right now'. The documentary came at a time when winds against immigration to Britain blow colder now again.

\section{DEFLECTION AND BREAK-AWAY INDIVIDUALS}

The material of the chapter shares a focus on 'break-away' paths or remarkable, key episode incidents (Thomsen using McAdams 2013) that brings to light particular social field's convivial forms of cohabitation and conflict. Victor exhibited in Tivoli, but later a conductor at college and then initiating a choir. His story is the tale of the self-made and adaptive newcomer which postcolonial Denmark so conveniently cherishes-and his achievements were certainly remarkable. However, such celebratory discourses, as Lapina notes, might allow inequalities to slip out of the debate (Lapina 2016: 39). We may be aware of the pros and cons of the healing-seeking or reconciliatory nature-and ask why they are shaped as they are and for whom are they portrayed? Furthermore, such narratives may perform a particular working-through of difficult lives (Ricoeur using Freud 1999: 5-11) towards an end point of 'success after all'. Kavanagh captures well lows and highs of Laurie's life, while the exhibition in Nakskov, taking us through 
Victors life as a visual memoir (with a strong focus on his public life), is somehow less multi-faceted.

Laurie was tightrope-dancing between ballet and football, before the vicious tackles of Spain. After 2 good years at West Bromwich, he was sold to Real Madrid at the age of 23, and from then on, with glimpses of genius, notably in the beginning, injuries make his trouble begin. He returned to England several times and in the course of his career plays for many clubs after his early days with first Leyton Orient, then West Bromwich-before the big sale to Real Madrid in the Summer of 1979. Ironically, one year before his death, he in 1988 joined Wimbledon FC. He was then in his early 30s, a more muscular figure, who had had to turn his previous habitual grace into something more solid after a plague of injuries. Wimbledon FC was a surprise. The club was a crazy gang of rough and tough-as un-Laurie as it could get (as John Barnes put it, in Kavanagh 2017: 89). Wimbledon FCs first team, apart from playing tough, had a tactic of just looping the ball into the opponent's defence and get people forward. Statistically it would higher the chances of scoring, to have the ball close to goal often, they believed. Somehow it worked; they reached the FA cup final in 1988 and win it. Laurie comes on the pitch as substitute. He had deflected again, joined another crowd, and despite all signs of break down, he was in the midst of another kind of conviviality.

\section{Play the Game Wilfully-And Playfully}

Valluvan writes about how ethnic differences should cease to require scrutiny (Valluvan 2016:207). He refers to Amin's work, where conviviality is defined as 'indifference to difference' (207). Research into conviviality, as for example Gilroy's work from 2004, discusses modes of interaction and cohabitation replacing or reworking older notions of multiculturalism or cosmopolitanism. The cases of Laurie and Victor can be grasped as stories of agency rather than stuckness, carrying redemptive plotting and generative life practices (after McAdams 2005), or stories to live by as markers of hope and encouragement - and thereby also as memories for the future; memory work to continue to play the 'game' 'wilfully' but also playfully.

Research, such as the material introduced in this chapter, that draws upon the use of biography, interviews, letters and diaries as a sort of historical records, can lead to questions around representation of past events. These genres carry their degree of 'noise', one could say. They may not be viewed as 'high fidelity' when it comes to information or facts about the 
actual past events, but rather as rich sources in the way they reveal how subject's did see themselves and their worlds, as Caine points out (2010: 75) - or rich in their ways of thinking in and about time, I would add. They are not just historical sources ('History' deals with collective time versus the arbitrary time of the individual life in autobiography, as Popkin notes, 2005: 11). Instead they are mediations of spaces of anxieties about failed projects and future imaginings (King using Stoller 2012: 19). Kavanagh, Laurie's biographer, maps a rich life but also a series of misgivings and a failed project. Laurie however kept returning. Victor may more easily fit into the redemptive life story tale, cosy material for a more pleasurable or convivial and postcolonial tale. The guy who made it through, and who taught us (he was a teacher) and who even whipped us (it may be stretching it, but here we have a man whose ancestors experienced 150 years of brutal slavery). At the exhibition in Nakskov in August 2017, a film of video letters of his former students reminiscing Victor is shown. A guy remembers he was given 25 beats for some sort of unruly behaviour. At beat number 10 , he is hurt and he pulls his hand aside. Then Victor starts from the beginning, whip 1, and so forth. It is however all told in a light-hearted, good-humoured way. The exhibition, and the video letters, celebrates Victor after all.

Some research says (Frank Larsen 2008) that he was also given the task of beating unruly boys. At this time, beatings were legal and common. The question is if the male teacher Victor was different from any other? Would he risk out or do differently than other teachers?

Victor was respected. He was often taking the role of yard guard during breaks. Often standing at the fence chatting with other students, being very social. Passers-by would look, his colour was different, but he also fitted in.

The school was a space of interdependence we could say. So is the football team. Nowicka and Heil note this importance of interdependence alongside the unremarkable, when trying to understand conviviality (2015: 14). Victor was possibly slapping, and definitely singing and giving music student Timme, the earlier mentioned music student of Victor (and his wife) had some of the most precious moments of their youth. Timme emphasised Victor's strong humanitarian values and his musical inspiration (interview, 2017), which later brought him and his wife to the music conservatory. 


\section{High Exposure And 'The Stopping Down' of Aperture}

Laurie and Victor both became highly exposed in their communities. Victor recalls how he and his half-sister Alberta were taken for a walk to the exhibition in Tivoli, after just arriving, and how all the whites wanted to pinch them or check them out. Laurie too, in other ways in the more multi-ethnic cities of London and Birmingham 70 years later. Laurie's white girlfriend Nikki recalls a stroll with Laurie after a night out. Some blokes approach them, threateningly, spitting at Nikki. Nikki tells Adrian Chiles how Laurie avoided one of the men's attack on him and in defence tipped him to the ground. Later, the guy, a fan of West Brom it appeared, slowly got up and realised '... you are Laurie, I love you...'. So, this was Laurie, the skilled footballer he was a fan of, not an ordinary black guy having a walk with his white girlfriend (Nikki Brown in Chiles 2016).

The exposed, framed and highly visible person can only respond with deflection, to keep a sense of self, we may argue. If one is put in one frame one day, and the next day or year seen as something else, this may force the framed to seek spaces of refuge or reinvention. From the cave to the choir, from the muddy pitches to offerings of a ballet career. Then later on to the crazy gang of Wimbledon. There were also roads not taken and myths followed. Interestingly, Victor continued to believe that he was on a mission to Denmark to teach and not to be sent back to St. Croix (Cornelins 1977; Frank Larsen 2008). Laurie never wrote his memoirs. Using Glissant's notes or call for opacity (1997: 193), we do not necessarily have to fully grasp either Laurie or Victor, or their 'stopping down' (reducing light coming in to the camera while gaining a depth of field/focus). Their deflections, or ways towards refuge, may be unclear for us, and still we can act in solidarity with them.

Glissant makes an interesting attempt at thick description of opaque or reclusive communication between him and a silent walker who kept passing by on a beach route near his garden and the ocean. Glissant had watched him many times passing, and they had noted each other, but the walker clearly wanted privacy. Glissant tried to call him politely with a hand gesture. The walker returned it with recognition, but also (in Glissant's interpretation, pp. 121-127) as a 'wink' or a 'hi' meaning: 'I have seen you, hi to you, but let us not go further in conversation'.

So, let us just be pleased with what we know about Laurie and Victor, what they gave, open, yet reclusive or opaque-and act in solidarity. 
Laurie and Victor were two different characters in various ways resurging or unleashing different aspects of their given, often racialised identities. They had their games against reduction or public attempts to 'corner them in any essence' (Glissant 1997: 192). Laurie's ballet-football, 'a black Nureyev' (famed Russian ballet dancer, Kavanagh 2017: 79), was just one mode or sign of his displacing of labelling. The same could be said of Victor's embrace of Danish songs, enlightenment and values of civilisationthe values he praised in his autobiography (1977), and which he thought he was taken to the West to teach.

\section{ENDing Notes}

Victor, brought to Denmark solely as a colonial 'artefact' for exhibiting purposes, was 30 years later becoming the star and the talk of small-town Nakskov with his love for music and his teaching skills and sociality. Later in life, he toured the country and then initiated a choir. Victor had married a Swedish white woman, had three kids and lived in that small town all his life. He was eventually buried next to his wife, as he wished, near the small town of Nakskov.

Laurie brought his English girlfriend, Nikki, with him to Madrid (the one interviewed by Chiles in the TV documentary and who experienced the assault when she and Laurie were out strolling). Nikki and Laurie separated some years later, but on friendly terms. Laurie had a child with Spanish Silvia a few years before his early death in a car crash in Madrid in 1989. Nikki, whom Laurie had met at a London dance floor just before he joined West Bromwich, was closing the casket. Laurie is buried in North London.

\section{Notes}

1. Laurie and the handful of other very talented black players that came into the best English league in the 1970s paved way for a rising generation of black footballers. The history of black footballers in Britain is eloquently documented in Onura's Pitch Black (2015).

2. John Akomfrah is a UK filmmaker of Ghanaian descent, a founder of the Black Audio Film Collective in 1982.

3. A recent film by Johan Akomfrah is his intimate portrait of Stuart Hall in The Stuart Hall Project (2014) compiling archival clips and interviews with Hall himself and with music by one of Hall's favourite artists, Miles Davis. The movie is at the same time a history of Britain and British cultural studies. Lola Young, Faye Ginsburg and I debated this movie at a screening and 
seminar event at Malmö University in September 2014, the debate later edited for publication in Høg Hansen, Young and Ginsburg, 2015 (see, e.g., Høg Hansen et al. 2016).

4. West Brom's football these days is a different affair. When the writing of this article was begun, the team were rock-bottom in premier league. When completed, they are in the second tier, just missing promotion to premier league.

5. The material of this chapter, alongside a range of other cases, is planned to be expanded and included in a monograph of 12 thematically related cases and life stories that reconstructs the journeys of enigmatic lives, tracing their private journeys and public exposures. The intended collection may include material from Britain and Denmark, Sweden, USA, Israel-Palestine, Tanzania and Mozambique. The discussions, notably the work on reclusive openness in this chapter, draw from e.g. Høg Hansen (2016).

6. Conservative MP Enoch Powell's strong anti-immigration speech in Birmingham, UK, in April 1968, which led to his sacking, but made Powell famous and it is commonly assumed that it triggered popular sentiment against immigration.

7. I am indebted to several commenter's for inspiring me to link reclusive openness to opacity and more closely discuss race under this theoretical framework; first of all, Meghan Tinsley (correspondence 22 January 2018, after a conference presentation in December 2017), but also the use or mentioning of Glissant by Kerry Byström, Oscar Hemer, Per-Markku Ristilammi and Temi Odumosu on various occasions.

8. Search for funding delayed the realisation of a memorial sculpture. A model is shown in Chiles documentary where Chiles and Cunningham's family visits an atelier with the work in progress. It is to be launched at the town centre of West Bromwich on 22 May 2019, see e.g., Guttridge (2019).

9. A formerly famed black defender at West Brom, Darren Moore, though in April 2018 took over managing at the club when they bottom of the premier league. He became the first Jamaican manager in a premier league club ever. A change of style to more attacking football and also more wins established him as a cherished character, also as manager. However, a series of bad results next spring (the club now were among the best in the second tier) led to an early sacking of Moore in March 2019.

\section{References}

Back, L., T. Crabbe, and J. Solomos. 2000. The Changing Face of Football. Oxford: Berg.

Bhabha, H. 1994. The Location of Culture. London: Routledge.

Burnton, S. 2016. “The West Brom Testimonial.” The Guardian, November 24. 
Cohen, P. 2017. Personal Email Correspondence, May 30. Feedback on Book Proposal.

Cornelins, V. 1977. Fra St. Croix til Nakskov. Copenhagen: Frimodts.

Caine, B. 2010. Biography and History. London: Palgrave.

Centre for Contemporary Cultural Studies, Gilroy, P. et al. 1982. The Empire Strikes Back. Birmingham: CCCS, University of Birmingham/Routledge.

Chiles, A. 2016. Whites vs Blacks: How Football Changed a Nation. Documentary, BBC.

Demos, T. J. 2009. “The Right to Opacity”. October 129: 113-128. https://doi. org/10.1162/octo.2009.129.1.113.

Frank Larsen, A. 2008. Slavernes slegt. Copenhagen: DR Forlag.

Freiesleben, Birgit. 1998. Fra St. Croix til Tivoli. En historisk betretning om to vestindiske borns lange rejse (This book is also available in English, with substantial parts of the autobiography included). Forlaget ACER.

Gilroy, P. 2004. After Empire: Melancholia or Convivial Culture. Abingdon: Routledge.

Gilroy, P. 2018. Personal Email Correspondence, April 3.

Glissant, É. 1997. Poetics of Relation. Ann Arbor: University of Michigan Press.

Guttridge, R. 2019. West Brom Three Degrees Statue to Be Unveiled in May. Express and Star, March 25, https://www.expressandstar.com/sport/football/ west-bromwich-albion/2019/03/25/west-brom-three-degrees-statue-to-beunveiled-in-may/.

Høg Hansen, A., L. Young, and F. Ginsburg. 2016. "Mediating Stuart Hall”. In Voice \& Matter, edited by O. Hemer and T. Tufte. Gothenburg: Nordicom.

Høg Hansen, A. 2016. "Reclusive Openness in the Life of Eugene Haynes." medium.com.

Kavanagh, D. 2017. Different Class: The Story of Laurie Cunningham. London: Unbound.

King, M. T. 2012. "Working with/in the Archives." In Research Methods for History, edited by L. Faire and S. Gunn, 13-29. Edinburgh: Edinburgh University Press.

Lapina, L. 2016. "Besides Conviviality." Nordic Journal of Migration Research 6(1): 33-41. https://doi.org/10.1515/njmr-2016-0002.

McAdams, Don. 2005. The Redemptive Self: Stories Americans Live By. Oxford: Oxford University Press.

Nowicka, Magdalena, and Tilmann Heil. 2015. "On the Analytical and Normative Dimensions of Conviviality and Cosmopolitanism.” Eberhard Karls University Lecture.

Nowicka, M., and S. Vertovec. 2014. "Comparing Convivialities: Dreams and Realities of Living-with-Difference." European Journal of Cultural Studies 17 (4): 341-354. https://doi.org/10.1177/1367549413510414.

Onunua, E. 2015. Pitch Black. London: Biteback Publishing. 
Ørvad, T. 2017. Interview by Anders Høg Hansen, October 17 ( Former Student of Victor Cornelius).

Popkin, J. 2005. History, Histories \& Autobiography. Chicago: University of Chicago Press.

Rees, J. 2016. "Whites vs Blacks: How Football Changed a Nation." The Telegraph, November 27.

Rees, P. 2014. The Three Degrees: The Men Who Changed British Football Forever. London: Constable.

Regis, C. 2010. My Story (As Told to Chris Green). London: André Deutsch.

Ricoeur, P. 1999. "Memory and Forgetting." In Questioning Ethics, edited by R. Kearney and M. Dooley, 5-11. London: Routledge.

Simek, Nicole. 2015. "Stubborn Shadows." Symploke 23 (1-2): 363-373. https:// muse.jhu.edu/article/605678.

Thomsen, Dorthe. 2013. Livshistorien. Århus Universitetsforlag.

Tinsley, M. 2018. Personal Email Correspondence, January 23.

Valluvan, S. 2016. "Conviviality and Multiculture: A Post-integration Sociology of Multi-ethnic Interaction.” Young 24 (3): 204-221. https://doi.org/10.1177/ 1103308815624061 .

Open Access This chapter is licensed under the terms of the Creative Commons Attribution 4.0 International License (http://creativecommons.org/licenses/by/ $4.0 /$ ), which permits use, sharing, adaptation, distribution and reproduction in any medium or format, as long as you give appropriate credit to the original author(s) and the source, provide a link to the Creative Commons license and indicate if changes were made.

The images or other third party material in this chapter are included in the chapter's Creative Commons license, unless indicated otherwise in a credit line to the material. If material is not included in the chapter's Creative Commons license and your intended use is not permitted by statutory regulation or exceeds the permitted use, you will need to obtain permission directly from the copyright holder.

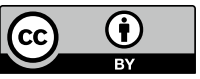

